\title{
Characterisation of yeast flora isolated from an artisanal Portuguese ewes' cheese
}

\author{
S. Pereira-Dias ${ }^{\text {a }}$, M.E. Potes ${ }^{b}$, A. Marinho ${ }^{c}$, M. Malfeito-Ferreira ${ }^{a}$, V. Loureiro ${ }^{a} * *$ \\ a Laboratório de Microbiologia, Departamento de Botânica e Engenharia Biológica, Instituto Superior de Agronomia, Tapada da Ajuda, \\ 1349-017 Lisboa, Portugal \\ ${ }^{\mathrm{b}}$ Departamento de Sanidade Animal e Vegetal, Universidade de Évora, Apartado 94, 7001 Évora Codex, Portugal \\ ${ }^{\mathrm{c}}$ Departamento de Zootecnia, Universidade de Évora, Apartado 94, 7001 Évora Codex, Portugal
}

Received 1 March 1999; received in revised form 20 January 2000; accepted 20 April 2000

\begin{abstract}
The evolution of the yeast flora was studied for an artisanal semi-hard ewes' cheese made from raw milk. Mean log 10 yeast counts per gram of cheese body ranged from 2.7 to 6.4 , with the higher counts observed after a ripening period of 30 days. The yeast population decreased thereafter and, at the end of curing process, reached values similar to those of the beginning. A total of 344 yeasts strains were randomly isolated from the curd and cheese body during the 60 days long ripening period. Esterase activity was common to almost all isolates (98\%) while proteolysis was observed in $12 \%$ of the total yeast population. The proportion of strains with positive glucose fermentation increased from $21 \%$ in the curd to $75 \%$ at the end of the ripening period. A total of 150 isolates representative of the physiological characteristics tested were examined with the API ID 32C system showing different degrees of quality of identification. Only $15 \%$ of the strains ( 23 isolates) were excellently identified being assigned to the species Candida zeylanoides. The most frequent species appeared to be Debaryomyces hansenii (anamorph Candida famata) and Candida intermedia. These two species amounted to $9 \%$ of the yeasts in the curd increasing to $86 \%$ at the end of the ripening period. (C) 2000 Elsevier Science B.V. All rights reserved.
\end{abstract}

Keywords: Cheeses; Yeast; Contamination; API system; Debaryomyces hansenii; Candida intermedia

\section{Introduction}

The main group of micro-organisms generally associated with cheese is composed by lactic bacteria although, nowadays, it is well recognised that yeasts isolated from cheese play a significant role in its

\footnotetext{
*Corresponding author. Tel.: + 351-21-363-8161; fax: + 35121-363-5031.

E-mail address: vloureiro@isa.utl.pt (V. Loureiro)
}

ripening (Fleet, 1990; Deak and Beuchat, 1996). The occurrence of yeasts in cheeses may contribute positively to the flavour development during the stage of maturation or, on the contrary, may lead to product spoilage (Fleet, 1990). The recovery of yeasts in high numbers (e.g. $10^{7}-10^{8} \mathrm{CFU} / \mathrm{g}$ ) and their ability to hydrolyse the milk fat suggest that cheese organoleptical characteristics might be influenced by yeasts (Fleet, 1990; Deak and Beuchat, 1996). Even in cheeses inoculated with bacterial 
starters, yeasts may be detected in counts as high as $10^{3} / \mathrm{g}$ (Sánchez et al., 1995; Gobbetti et al., 1997). The main defects of yeast activity include the production of fruity, bitter or yeasty off-flavours and the appearance of a gassy, open texture, being difficult to separate beneficial from detrimental effects (Fleet, 1990). In addition, the defect of cheese surface discoloration has been recently related with yeast activity (Carreira et al., 1998).

The cheese studied is a semi-hard variety of ewes' cheese produced in the southern region of Portugal in the neighbourhood of Évora city. The cheeses are made with raw milk without the addition of starters and the maturation is characterised by the predominance of lactic bacteria and enterococci (Potes and Marinho, 1996). The presence of yeasts was also observed by these authors, however a detailed study on this group of micro-organisms has not been carried out so far. The aim of this work was to characterise selected physiological characteristics and to identify the yeasts present during the ripening process of this artisanal ewes' cheese.

\section{Material and methods}

\subsection{Cheese samples}

The cheese samples were collected in an artisanal dairy in the Évora district. The cheeses, weighing 90 $\mathrm{g}$, were produced on two different dates (April and May) during the same season. The ripening followed the usual process of this dairy (Potes and Marinho, 1996) and cheese samples were taken from the curd and from cheeses after about 30, 45 and 60 days of maturation. A total of three to five cheeses were analysed at each sampling date.

\subsection{Yeast enumeration, isolation and maintenance}

An amount consisting of $10 \mathrm{~g}$ of product was taken from the body (inner part) of the cheeses without contact with the cheese rind (surface layer), diluted in $90 \mathrm{ml}$ Ringer solution (Oxoid, Unipath Ltd, Basingstoke, UK) and homogenised in a blender (Waring Blender 700, model 31BL46, Fisher Scientific, USA) for $1 \mathrm{~min}$ at $2000 \mathrm{rev} . / \mathrm{min}$. Serial dilutions were prepared and $1 \mathrm{ml}$ was incorporated in triplicate plates of Rose Bengal (Oxoid) added 100 ppm of chloramphenicol (Oxoid). Incubation was carried out over 5 days at $25^{\circ} \mathrm{C}$. Counts are presented as average of the logarithm $\left(\log _{10}\right)$ of CFU/g of cheese for each sampling date. For isolations, colonies were randomly selected from each plate, according to: (i) $50 \%$ of the total colonies when the number of counts was between 0 and 10; (ii) $10 \%$ of the total colonies when their number was between 10 and 100; and (iii) $5 \%$ of the total colonies when counts were between 100 and 300. Strains were purified by subsequent streaking onto GYP medium (20 g/l glucose (Merck, Darmstadt, Germany), 5 g/1 yeast extract (Difco Laboratories, Detroit, USA), 10 $\mathrm{g} / 1$ peptone (Difco) and $20 \mathrm{~g} / 1$ agar, $\mathrm{pH}$ 6.0) and maintained on slants of YM agar $(3 \mathrm{~g} / 1$ malt extract (Difco), $3 \mathrm{~g} / 1$ yeast extract (Difco), $5 \mathrm{~g} / 1$ peptone (Difco), $10 \mathrm{~g} / 1$ glucose (Merck) and $20 \mathrm{~g} / 1$ agar) at $4^{\circ} \mathrm{C}$. Fresh cultures in YM slants $(24-48 \mathrm{~h})$ were prepared before performing the tests described below.

\subsection{Morphological characterisation}

Colonies on WLN agar (60 g/l WLN (Sigma Chemical Co., St. Louis, USA) and $20 \mathrm{~g} / 1$ agar) after 4 days, at $25^{\circ} \mathrm{C}$, were examined.

\subsection{Physiological characterisation}

\subsubsection{Hydrolysis of urea}

The urea hydrolysing ability was tested using Christensen's urea agar (Christensen, 1946): $1 \mathrm{~g}$ peptone (Difco), $1 \mathrm{~g}$ glucose (Merck), $5 \mathrm{~g}$ sodium chloride (Merck), $0.012 \mathrm{~g}$ phenol red (MandB, Dagenham, UK), and $20 \mathrm{~g}$ agar were dissolved in $900 \mathrm{ml}$ of distilled water. The $\mathrm{pH}$ was adjusted to 6.8 with $1 \mathrm{M} \mathrm{NaOH}$. Aliquots of $4.5 \mathrm{ml}$ of the medium were dispensed in $16 \mathrm{~mm}$ cotton plugged tubes and sterilised at $121^{\circ} \mathrm{C}$ for $15 \mathrm{~min}$. Then $0.5 \mathrm{ml}$ of a $20 \%$ $(\mathrm{w} / \mathrm{v})$ filter sterilised $(0.22 \mu \mathrm{m}$ pore size, Millipore Corporation, Bedford, MA, USA) urea (Sigma Chemical Co., St. Louis, USA) solution was added. A streak of fresh culture was used to inoculate these agar slants and incubation was carried out at $25^{\circ} \mathrm{C}$ for 2 days. Positive tests were given by change in the colour of the medium from yellow to intense pink. 


\subsubsection{Alkalising power}

Plates of a medium containing bromothymol blue (Merck) and the amino acids asparagine, L-glutamine and glycine (Carreira et al., 1998) were inoculated and incubated for 5 days at $25^{\circ} \mathrm{C}$. The change in colour from yellow ( $\mathrm{pH}$ 6.8) to blue ( $\mathrm{pH}$ 7.6) indicated alkaline conditions caused by the yeast.

\subsubsection{Form of growth in liquid medium and glucose fermentation}

Tubes with GYP broth were inoculated and incubated for a maximum of 12 days at $25^{\circ} \mathrm{C}$. Production of film, ring or turbidity was checked visually. Glucose fermentation was assessed by observing gas production in Durham tubes included in the GYP broth.

\subsubsection{Cycloheximide resistance}

Cultures were inoculated in GYP broth containing 4 or $1000 \mathrm{ppm}$ cycloheximide (Sigma). Growth was recorded after 12 days of incubation at $25^{\circ} \mathrm{C}$.

\subsubsection{Esterase activity}

Strains were inoculated on plates of tributyrin medium (40 g/l gelatine (Difco), $24 \mathrm{~g} / 1$ tryptone glucose extract agar (Oxoid), $5 \mathrm{~g} / 1$ tributyrin (Sigma), $5 \mathrm{~g} / 1$ Tween 80 (Sigma), and $10 \mathrm{ml} / 1$ of a solution of Nilus blue sulfate (Sigma) obtained by dissolving $66 \mathrm{mg}$ of this compound in $100 \mathrm{ml}$ of water) and incubated at $25^{\circ} \mathrm{C}$ over $4 / 5$ days. After autoclaving the $\mathrm{pH}$ of this medium was 7.0 \pm 0.2 . Positive results were recorded when colonies were surrounded by a transparent halo over a blue background.

\subsubsection{Proteolytic activity}

Strains were inoculated on plates of milk medium (250 $\mathrm{ml}$ of whole milk plus $500 \mathrm{ml}$ of $5 \mathrm{~g} / 1$ yeast extract (Difco), $10 \mathrm{~g} / 1$ peptone (Difco), $20 \mathrm{~g} / 1$ glucose (Merck) and $20 \mathrm{~g} / 1$ agar) incubated at $25^{\circ} \mathrm{C}$ over 10 days. Positive results were recorded when colonies were surrounded by a transparent halo.

\subsection{Yeast identification}

Strains for identification were selected based on the morphological and physiological characterisation. The number of strains selected was proportional to the number of strains with similar physiological and morphological characteristics. For identification the miniaturised system API ID 32C (BioMérieux S.A., Marcy-L'Étoile, France) was used following the instructions given by the suppliers (Anonymous, 1993). Supplementary tests were performed whenever the identification was considered doubtful by the software API LAB (BioMérieux). These tests, i.e. pseudomycelium formation, nitrate assimilation, growth in tiamin and aesculin, growth at 37 and $42^{\circ} \mathrm{C}$, were performed according to Kreger-van $\mathrm{Rij}$ (1984).

\section{Results}

Mean $\log _{10}$ yeast counts per gram of cheese ranged from 2.7 to 6.4 , with the higher counts observed in the first production season (April) and after a ripening period of 30 days (Fig. 1). In the second production season (May) the maximum yeast population were about one order of magnitude lower after the same period. However the evolution of the yeast counts showed a similar pattern in both seasons (Fig. 1).

A total of 344 yeast strains were isolated from the curd and cheese body showing nine different morphological types (Table 1). Most strains presented the morphological types VI $(61 \%)$ and V (21\%). However the evolution of the different types during ripening was characterised by a decrease in the proportion of the type $\mathrm{V}$ and by an increase in type VI. Furthermore, the pink and orange pink colonies of types VIII and IX were only isolated from the curd.

The physiological characterisation of these 344 strains is also shown in Table 1. The overall characteristics were similar in both producing seasons (April and May) and so the average results are given in Table 1. The predominant strains belong to the family Ascomycetaceae (92\%, urease negative). The predominance of ascomycetous yeasts was not so high in the curd mainly because of the presence of urease positive yeasts characterised by the morphological types VIII and IX yeasts (pink and orange pink colonies). The proportion of isolates with alkalizing activity decreased from $65 \%$ in the curd to about $35 \%$ in the remaining curing period. Glucose fermentation positive strains increased from $21 \%$ in the curd to $88 \%$ and $75 \%$ after 45 and 60 days of 


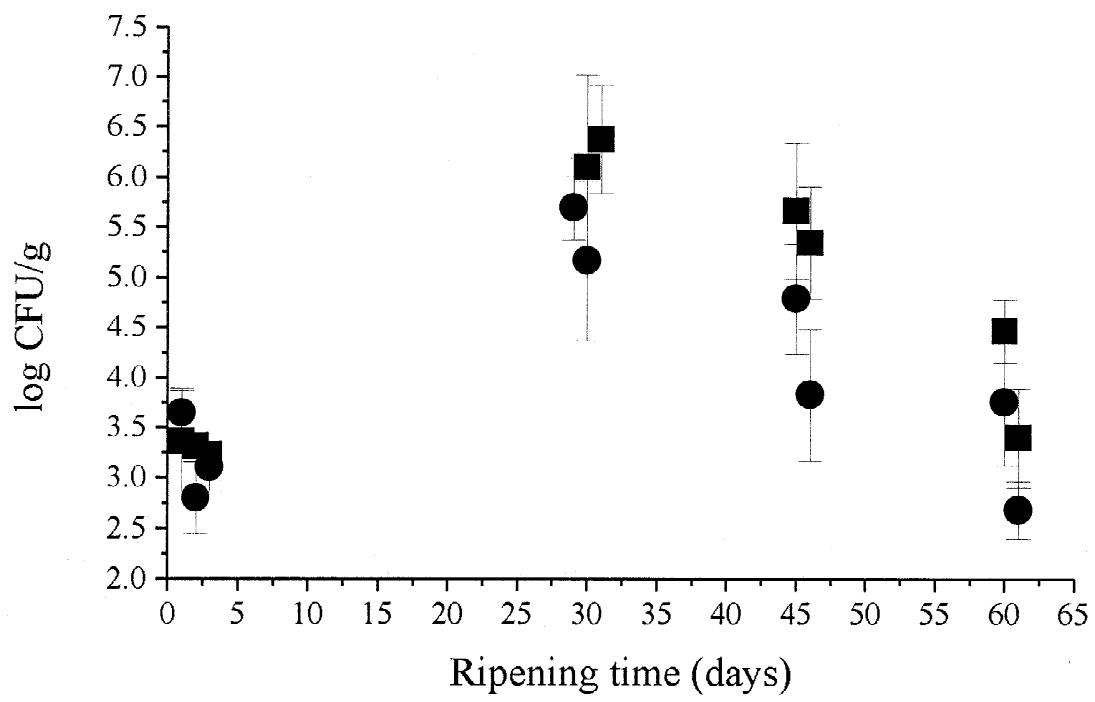

Fig. 1. Evolution of yeast counts $\left(\log _{10} \mathrm{cfu} / \mathrm{g}\right)$ in cheese body during the ripening period of artisanal ewes' cheese (production seasons: April; O, May).

Table 1

Physiological and morphological characterisation of yeasts isolated during cheese ripening period (results are indicated as percentage of positive tests and are the average of two production seasons)

\begin{tabular}{|c|c|c|c|c|c|}
\hline Test & $\begin{array}{l}\text { Curd } \\
(86)^{\mathrm{a}}\end{array}$ & $\begin{array}{l}30 \text { days } \\
(93)^{\mathrm{a}}\end{array}$ & $\begin{array}{l}45 \text { days } \\
(90)^{\mathrm{a}}\end{array}$ & $\begin{array}{l}60 \text { days } \\
(75)^{\mathrm{a}}\end{array}$ & $\begin{array}{l}\text { Total } \\
(344)^{a}\end{array}$ \\
\hline Urease & 27 & 2 & 0 & 5 & 8 \\
\hline Alkalisation & 65 & 29 & 39 & 35 & 56 \\
\hline Glucose fermentation & 21 & 54 & 88 & 75 & 61 \\
\hline Surface growth & 31 & 59 & 74 & 64 & 60 \\
\hline Esterase activity & 99 & 98 & 97 & 100 & 98 \\
\hline Proteolytic activity ${ }^{\mathrm{b}}$ & 14 & 21 & 5 & 6 & 12 \\
\hline Cycloheximide (4 ppm) & 74 & $81 \nabla$ & 93 & 80 & 84 \\
\hline Cycloheximide $(1000 \mathrm{ppm})^{\mathrm{b}}$ & 26 & 47 & 20 & 12 & 27 \\
\hline \multicolumn{6}{|l|}{ Morphological types $^{\mathrm{c}}$} \\
\hline I & 2 & 0 & 0 & 6 & 2 \\
\hline II & 4 & 0 & 0 & 0 & 1 \\
\hline III & 1 & 4 & 4 & 2 & 3 \\
\hline IV & 1 & 1 & 0 & 0 & $<1$ \\
\hline V & 43 & 32 & 8 & 1 & 21 \\
\hline VI & 22 & 60 & 81 & 88 & 61 \\
\hline VII & 0 & 3 & 7 & 3 & 4 \\
\hline VIII & 22 & 0 & 0 & 0 & 5 \\
\hline IX & 5 & 0 & 0 & 0 & 1 \\
\hline
\end{tabular}

${ }^{\mathrm{a}}$ Total number of strains isolated.

b Total number of strains tested were 42,38, 39 and 33 in the curd, after 30, 45 and 60 days, respectively.

${ }^{\mathrm{c}}$ The features edge, elevation, surface, optical and colour are as follows: I, circular with rootlike projections, rough, matte, opaque and cream; II, circular with rootlike projections, center peak, shiny, opaque and cream; III, circular with round projections, rough plane, rough matte, opaque and cream; IV, evenly circular, center peak, shiny, opaque and cream; V, evenly circular, convex, shiny, opaque and cream; VI, evenly circular, convex, matte, opaque and cream; VII, evenly circular, convex, rough matte, opaque and cream; VIII, evenly circular, convex, shiny, opaque and pink; IX, evenly circular, convex, shiny, opaque and orange pink. 
ripening, respectively. The esterase activity was a feature common to almost all strains isolated (98\%) during cheesemaking process. On the contrary, proteolytic activity was only detected in $12 \%$ of the isolates.

From the 344 isolated 150 were selected to be identified by the API ID 32C. The identification results are shown in Table 2 . Only $15 \%$ of the strains (23 isolates) were excellently identified being assigned to the species Candida zeylanoides. For the other isolates the identifications at species level were: $\operatorname{good}(13 \%$ of the strains); doubtful $(43 \%)$; and good at the genus level (5\%). A total of 35 isolates (23\%) did not match any of the identities given by API ID 32C.

Most strains belong to the species Debaryomyceshansenii (anamorph Candida famata), Candida intermedia and C. zeylanoides (Table 2). The difference between the species $C$. famata and $C$. intermedia was only related with formation of pseudomycelium which by the API system is considered positive for $99 \%$ of C. intermedia strains and $1 \%$ of D. hansenii/C. famata strains. Other less frequently isolated strains belong to the species Candida curvata (synonym Cryptococcus curvatus; Kurtzman and Fell, 1998) and to the genus Rhodotorula. However, species distribution during cheese maturation was not constant. In fact, $C$. curvatus and Rhodotorula spp. were only recovered from the curd while the occurrence of $D$. hansenii/C. famata and $C$. intermedia increased with ripening time. In addition, $C$. zeylanoides was not isolated from the final stages of maturation.

The species $D$. hansenii/C. famata and $C$. intermedia showed the most frequent colony morphology of the type VI. The type V was characteristic of $C$. zeylanoides and C. curvata and the pink (type VIII) or orange pink (type IX) colonies were isolates of Rhodotorula spp.. However, in few isolates, the same species presented several colony morphologies which were coincident with types of other species (see Table 2).

The relation between the identification and some relevant technological properties (Table 3 ), revealed that esterase activity was common to all species while proteolysis was observed in $48 \%$ of the strains assigned to $C$. zeylanoides and was absent from $D$. hansenii/C.famata, C. intermedia and Rhodotorula spp.. Among the six strains of $C$. curvata tested only one showed proteolytic activity. The alkalizing effect was positive in $11 \%$ of $C$. zeylanoides, $43 \%$ of $C$. intermedia, $44 \%$ of D. hansenii/C. famata, $67 \%$ of C. curvata and in $90 \%$ of the Rhodotorula spp. strains. Most strains of D. hansenii/C. famata (91\%) and $C$. intermedia $(73 \%)$ were glucose fermentation positive while most $C$. zeylanoides were negative (84\%) and all C. curvata and Rhodotorula spp. were negative.

Table 2

Identification of the yeasts isolated during cheese ripening period using the system API ID 32C (results were obtained in two production seasons and are indicated as percentage of total isolates identified)

\begin{tabular}{|c|c|c|c|c|c|c|c|}
\hline Species & $\begin{array}{l}\text { Curd } \\
(34)^{\mathrm{a}}\end{array}$ & $\begin{array}{l}30 \text { days } \\
(32)^{\mathrm{a}}\end{array}$ & $\begin{array}{l}45 \text { days } \\
(26)^{a}\end{array}$ & $\begin{array}{l}60 \text { days } \\
(23)^{a}\end{array}$ & $\begin{array}{l}\text { Total } \\
(115)^{\mathrm{a}}\end{array}$ & $\begin{array}{l}\text { Quality of } \\
\text { identification }^{\text {a }}\end{array}$ & $\begin{array}{l}\text { Morphological } \\
\text { type }^{\text {a }}\end{array}$ \\
\hline Candida curvata & 18 & 0 & 0 & 0 & 5 & Doubtful (6) & V (5), IV (1) \\
\hline Candida famatal & 3 & 31 & 56 & 52 & 33 & Good (11) & VI (9), III (1), VII (1) \\
\hline Debaryomyces hansenii & & & & & & Doubtful (27) & VI (25), VII (1), V (1) \\
\hline Candida humicola & 3 & 0 & 4 & 0 & 2 & Doubtful (2) & $\mathrm{V}(2)$ \\
\hline \multirow{2}{*}{ Candida intermedia } & 6 & 19 & 23 & 34 & 18 & Good (3) & VI (3) \\
\hline & & & & & & Doubtful (19) & VI (16), VII (2), IV (1) \\
\hline Candida parapsilosis & 0 & 3 & 0 & 0 & 1 & Doubtful (1) & III (1) \\
\hline \multirow[t]{2}{*}{ Candida zeylanoides } & 26 & 44 & 15 & 0 & 23 & Excellent (23) Doubtful (4) & V (22), VI (1) \\
\hline & & & & & & & $\mathrm{V}(4)$ \\
\hline Rhodotorula minuta & 3 & 0 & 0 & 0 & 1 & Good (1) & IX (1) \\
\hline Rhodotorula glutinis & 3 & 0 & 0 & 0 & 1 & Good (1) & IX (1) \\
\hline Rhodotorula rubra & 24 & 0 & 0 & 0 & 7 & Good genus (8) & VIII (8) \\
\hline Pichia carsonii & 0 & 3 & 0 & 8 & 3 & Doubtful (3) & VI (2), VII (1) \\
\hline Pichia etchelsii & 9 & 0 & 0 & 0 & 3 & Doubtful (3) & I (1), III (1), IX (1) \\
\hline Trichosporon cutaneum & 6 & 0 & 0 & 4 & 3 & Good (3) & I (1), V (2) \\
\hline
\end{tabular}

\footnotetext{
${ }^{a}$ The number of strains is indicated between brackets.
} 
Table 3

Physiological characteristics of the species isolated most frequently during cheese ripening (results indicated as percentage of positive reactions)

\begin{tabular}{llllcrr}
\hline Species $^{\mathrm{a}}$ & $\begin{array}{l}\text { Esterase } \\
\text { activity }\end{array}$ & $\begin{array}{l}\text { Alkalising } \\
\text { power }\end{array}$ & $\begin{array}{l}\text { Proteolytic } \\
\text { activity }\end{array}$ & $\begin{array}{l}\text { Glucose } \\
\text { fermentation }\end{array}$ & $\begin{array}{l}\text { Lactose } \\
\text { assimilation }\end{array}$ & $\begin{array}{l}\text { Lactate } \\
\text { assimilation }\end{array}$ \\
\hline Rhodotorula spp. (10) & 100 & 90 & 0 & 0 & 10 & 10 \\
Candida curvata (6) & 100 & 67 & 16 & 0 & 00 & 83 \\
Candida zeylanoides (27) & 96 & 11 & 48 & 26 & 0 & 0 \\
Candida intermedia (22) & 95 & 43 & 0 & 93 & 100 & 95 \\
Candida famatal & 100 & 44 & 0 & & & 84 \\
Debaryomyces hansenii (38) & & & & & \\
\hline
\end{tabular}

${ }^{\mathrm{a}}$ The number of strains is indicated between brackets.

The utilisation of the API system comprised two assimilation tests (lactose and lactate) which may have significance in cheese making. Lactose positive strains represented $45,63,88$ and $100 \%$ of the isolates in the curd, after 30,45 and 60 days of curing, respectively. The corresponding figures for lactate positive strains were $39,54,68$ and $85 \%$ of the yeast flora submitted to the API tests. The relation between these abilities and the species isolated is shown in Table 3. Concerning the identified strains, all C. zeylanoides, Rhodotorula rubra and Rhodotorula glutinis were lactose and lactate negative whereas the single isolate of Rhodotorula minuta was positive in both reactions. On the contrary, 100 and $83 \%$ of C. curvata strains assimilated lactose and lactate, respectively. $C$. intermedia assimilated lactose and lactate for 100 and $95 \%$ of the strains, respectively. Concerning $D$. hansenii/C. famata, the respective proportions were 100 and $84 \%$.

\section{Discussion}

Yeast counts measured in the cheese at the end of the ripening period were within the range reported by other authors (Nuñez et al., 1981; Chavarri et al., 1995; Fleet and Mian, 1987; Poullet et al., 1991; Litpoulou-Tzanetaki and Tzanetakis, 1992, Marcellino and Benson, 1992; Callon et al., 1994; Mor-Mur et al., 1994; Freitas et al., 1996; Hassouna et al., 1996). Similar evolution of yeast flora during ripening has also been observed and has been related with physico-chemical alterations in the cheese during ripening such as $a_{\mathrm{w}}$ decrease by dehydration (Nuñez et al., 1981; Fleet, 1990; Macedo et al., 1993; Freitas et al., 1996). However, constant yeast counts during ripening have been reported as well (LitpoulouTzanetaki and Tzanetakis, 1992; Marcellino and Benson, 1992; Mor-Mur et al., 1994).

The majority of isolates belong to the Ascomycetaceae family as usually reported (see reviews of Tudor and Board, 1993; Deak and Beuchat, 1996), although a relatively higher proportion of basidiomycetous yeasts was present in the curd.

Our results showing high yeast counts together with a esterase activity shared by almost all strains isolated agree with the opinion of other authors which state that yeasts may be an important microbial group determining the flavour and texture characteristics of the cheeses (Fleet, 1990; Deak and Beuchat, 1996). On the contrary, only a small proportion of strains showed proteolytic activity, as already observed by Besançon et al. (1992). In addition, we showed that proteolytic activity was preferentially present in the curd isolates and at the beginning of the ripening period. However, recently other methods for assessing the proteolytic activity, based on the breakdown of casein determined by capillary electrophoresis, seem to be more accurate to determine this activity (Clausen et al., 1997). Besançon et al. (1992) also considered that nitrate assimilation is an important technological feature of cheese yeasts but our results indicate otherwise because the strains of the most frequent genus isolated (Candida spp.) were all nitrate negative, in agreement with the respective biochemical results provided by Kurtzman and Fell (1998).

The presence of fermentative metabolism seems to be necessary to keep yeast viability in cheese body during ripening. In fact, fermentation ability was observed in $21 \%$ of the curd isolates while after 45 
days of ripening this proportion increased to about $80 \%$. These results are probably the reflect of decreasing oxygen availability in cheese body during maturation.

The increase in cheese $\mathrm{pH}$ is considered important to cheese making because it stimulates proteolytic bacteria activity (Fleet and Mian, 1987; Deak and Beuchat, 1996). This pH change may be achieved by yeast alkalising power (Carreira et al., 1998) and by lactate assimilation (Fleet and Mian, 1987; Deak and Beuchat, 1996). The former characteristic was predominant at the beginning of curing because it was common to $90 \%$ Rhodotorula spp. strains. During ripening the percentage of strains with alkalizing effect decreased and was kept constant due to the presence of this feature in about $44 \%$ of the $D$. hansenii/C. famata and C. intermedia strains. However, the total numbers of yeasts having alkalising power was similar because of the increase in yeast population during maturation. The increase in the numbers of isolates from these species was also responsible for the gradual increase in the proportions of lactate-positive strains during the maturation process.

It is worth noticing that $D$. hansenii/C. famata and $C$. intermedia were only differentiated by pseudomycelium formation which is considered an unreliable characteristic for taxonomic purposes (Deak, 1991). Furthermore, the data base of the API system refers that $1 \%$ of $D$. hansenii may show pseudomycelium while according to the data base of Deak and Beuchat (1996) this proportion is $15 \%$. Therefore, it is possible that these strains of $C$. intermedia are, in fact, of $D$. hansenii which is a far more common contaminant of cheeses. Thus, during ripening there is only one type of dominant yeasts as these two species represent more than $75 \%$ of the yeast population recovered after 45 days of curing. On the contrary, the two most frequent species of Candida in the curd behaved differently: C. curvata was not recovered from the cheese body and $C$. zeylanoides levels decreased after 30 days of maturation (see Table 2). This differing behaviour may be related to the absence of fermentative ability by $C$. curvata strains and with the less frequent fermentative ability among $C$. zeylanoides thus limiting their growth under the semianaerobic or anaerobic conditions in cheese body. Nevertheless, all species are able to play a particular role in cheese ripening because they have at least one physiological activity with technological significance, as summarised in Table 3.

Observation of colony morphology may be used as an approximate indicator of species variability even if either different species showed the same morphology or different morphologies were observed for the same species. In fact, the most represented colony types were $\mathrm{V}$ and VI corresponding to $C$. zeylanoides and $D$. hansenii/C. famata plus $C$. intermedia, respectively (see Table 2). After 60 days of ripening $88 \%$ of the strains showed the colony type VI that corresponded to $D$. hansenii/C. famata and $C$. intermedia.

The identification by the API ID 32C system was found to be quite labourious and the results obtained were frequently doubtful. The need to use additional tests when the quality of identification was poor increased significantly the time and work involved. The identification of the species described below remains to be validated by molecular techniques which use in microbial ecology studies has been in constant increase (Van der Vossen and Hofstra, 1996).

The species $D$. hansenii/C. famata is well known as contaminant of other cheeses (Nahabieh and Schmidt, 1990; Besançon et al., 1992; Rohm et al., 1992; Callon et al., 1994; López-Diaz et al., 1995; Freitas et al., 1996; Carreira et al., 1998) and its isolation is related with the abilities to ferment or assimilate lactose, to assimilate lactic and citric acids, to produce lipases and proteases and to resist to high $\mathrm{NaCl}$ concentrations (Fleet and Mian, 1987).

The group of 'pink yeasts', like $R$. rubra or $R$. glutinis was isolated only in the curd, being absent during ripening. These species also have the abilities to assimilate lactose and organic acids and to produce lipases and proteases (Fleet and Mian, 1987) and are normally recovered in relative low numbers (López-Diaz et al., 1995). Their origin is related with air contamination (Tudor and Board, 1993) and their absence from ripened cheese body is probably due to lower resistance to decreasing $a_{\mathrm{w}}$ values and their strict aerobic metabolism. A similar result was reported by Freitas et al. (1995) in another type of artisanal Portuguese cheese, where Rhodotorula spp. represented $50 \%$ of the total counts in the beginning of the ripening period after which they were not recovered.

In broad terms the other species isolated during 
the course of this work have already been reported in other types of cheeses. C. intermedia has been isolated from Camembert and Blue-veined cheeses (Roostita and Fleet, 1996) and from French goat cheese (Nahabieh and Schmidt, 1990). C. zeylanoides and $C$. parapsilosis were isolated from Spanish blue-cheese (López-Diaz et al., 1995). Nahabieh and Schmidt (1990) also isolated the species C. curvata (synonym of Cryptococcus curvatus, Kurtzman and Fell, 1998) which has been concerned with human or animal sources and appears to be related to the genus Trichosporon (Kurtzman and Fell, 1998). Candida humicola (synonym Cryptococcus humicolus) is also considered to be related with the genus Trichosporon (Kurtzman and Fell, 1998) and is a common contaminant of cheese plants (Tudor and Board, 1993). The isolation of the species Trichosporon cutaneum was reported by Nahabieh and Schmidt (1990) and is usually concerned with environmental, human or animal contamination (Deak and Beuchat, 1996; Kurtzman and Fell, 1998). Pichia etchelsii (synonym Debaryomyces etchelsii) and Pichia carsonii (synonym Debaryomyces carsonii) have been isolated less frequently and reference to these species in cheeses have not been found.

The main differences from the cheese related species reported in literature concern the absence of Kluyveromyces spp. and Yarrowia lipolytica, which have been broadly isolated from cheeses (Fleet, 1990; Tudor and Board, 1993; Deak and Beuchat, 1996). Y. lipolytica has been isolated from radial slices (Freitas et al., 1996) or from the rind (Carreira and Loureiro, 1998; Carreira et al., 1998) of several types of artisanal Portuguese ewes' cheeses. Its absence from the cheeses analysed may be explained by its strictly aerobic growth that is not favoured under the preferential anaerobic conditions in semihard cheese body. These results show that a careful sampling technique must be undertaken when studying the yeast flora of cheeses because the composition of the rind and body flora are probably different.

In other Portuguese ewe's or goat's cheeses Kluyveromyces spp. was also absent (Freitas et al., 1996; Carreira et al., 1998) or was isolated in a maximum percentage of $12.5 \%$ (Macedo et al., 1995). Roostita and Fleet (1996) have observed a lower frequency of Kluyveromyces spp. when com- paring Australian Camembert cheeses with others of French origin. Moreover, Nahabieh and Schmidt (1990) referred that the yeast flora is different in goat's, ewe's or cow's cheese, stating that in goat's cheese $Y$. lipolytica and $C$. intermedia have a significantly higher occurrence than in cow's cheese. The use of pasteurisation does not seem to be a selective factor enhancing the occurrence of Kluyveromyces spp. (Nahabieh and Schmidt, 1990). Therefore, the absence of Kluyveromyces spp. from the cheeses studied may be related with the specificity of the respective ecological niche.

\section{Acknowledgements}

This work was supported by the EU project AIR2-CT93-830.

\section{References}

Anonymous, 1993. Analytical Profile Index ID 32C system. BioMérieux, Marcy-1'Étoile, France.

Besançon, X., Smet, C., Chabalier, C., Rivermale, M., Reverbel, J.P., Ratomahenina, R., Galzy, P., 1992. Study of surface yeast flora of Roquefort cheese. Int. J. Food Microbiol. 17, 9-18.

Callon, C., Chataud, J., Vanderbecken, F., Larpent, J., 1994. Isolement et identification des levures de la flore interne de divers types de fromages. Microbiol. Alim. Nut. 12, 23-29.

Carreira, A., Loureiro, V., 1998. A differential medium to detect Yarrowia lypolytica within 24 hours. J. Food Mycol. 1, 3-12.

Carreira, A., Paloma, L., Loureiro, V., 1998. Pigment producing yeasts involved in a brown surface discoloration of ewes' cheese. Int. J. Food Microbiol. 41, 223-230.

Chavarri, F., Nuñez, J., Bautista, L., Nuñez, M., 1995. Factors affecting the microbiological quality of Burgos and Villalon cheeses at the retail level. J. Food Prot. 48, 865-869.

Christensen, W.B., 1946. Urea decomposition as a means of differentiating Proteus and Paracolor cultures from each other and from Salmonella and Shigella types. J. Bacteriol. 52, 461-466.

Clausen, M., Hansen, T., Jakobsen, M., 1997. Characterization of yeasts isolated from Mozarella cheese by patterns of whole cell protein electrophoresis, casein breakdown and release of free fatty acids from butter fat. Abstracts of the 18th International Specialized Symposium on Yeasts, 24th August-29th August, pp. 7-22, Bled, Slovenia.

Deak, T., 1991. Foodborne yeasts. Adv. Appl. Microbiol. 36, 179-278.

Deak, T., Beuchat, L.R., 1996. Handbook of Food Spoilage Yeasts. CRC Press, New York.

Fleet, G.H., Mian, M.A., 1987. The occurrence and growth of yeasts in dairy products. Int. J. Food Microbiol. 4, 145-155. 
Fleet, G., 1990. Yeasts in dairy products - a review. J. Appl. Bacteriol. 68, 199-211.

Freitas, A.C., Pais, C., Malcata, F.X., Hogg, T.A., 1996. Microbiological characterization of Picante da Beira Baixa cheese. J. Food Prot. 59, 155-160.

Gobbetti, M., Corsetti, A., Smacchi, E., De Angelis, M., Rossi, J., 1997. Microbiology ond biochemistry of Pecorino Umbro cheese during ripening. Ital. J. Food Sci. 9, 111-126.

Hassouna, M., Nafti, A., Ghrir, R., 1996. L'affinage d'un fromage à pâte molle et à croûte fleuri de type Camembert au lait cru de brebis: aspects microbiologiques et physico-chimiques. Sci. Alim. 16, 187-203.

Litpoulou-Tzanetaki, E., Tzanetakis, N., 1992. Microbiological study of white-brined cheese made from raw goat milk. Food Microbiol. 9, 13-19.

Kreger-van Rij, N.J.W. (Ed.), 1984. The Yeasts, a Taxonomic Study, 3rd Edition. Elsevier, Amsterdam.

Kurtzman, C., Fell, J., 1998. The Yeasts, a Taxonomic Study, 4th Edition. Elsevier, Amsterdam.

López-Diaz, T., Santos, J.-A., Prieto, M., García-López, M.-L., Otero, A., 1995. Mycoflora of a traditional Spanish blue cheese. Neth. Milk. Dairy J. 49, 191-199.

Macedo, A.C., Malcata, F.X., Hogg, T.A., 1995. Microbiological profile in Serra ewe's cheese during ripening. J. Appl. Bacteriol. 79, 1-11.

Marcellino, N., Benson, D., 1992. Scanning electron and light microscopic study of microbial succession on Bethlehem St. Nectaire Cheese. Appl. Environ. Microbiol. 58, 3448-3454.

Mor-Mur, M., Carretero, C., Pla, R., Guamis, B., 1994. Microbiological changes during ripening of Cendrat del Montsec, a goat's milk cheese. Food Microbiol. 11, 177-185.
Nahabieh, F., Schmidt, J., 1990. Contribution à l'étude de la flore levure de quelques grands types de fromages de chévre. Lait 70, 325-343.

Nuñez, M., Medina, M., Gaya, P., Dias-Amado, C., 1981. Les levures et les moissures dans le fromage bleu de Cabrales. Lait 61, 62-79.

Potes, M.E., Marinho, A., 1996. Microbial changes of the cheese produced in the region of Évora during ripening period (in portuguese). International Symposium Los fundamentos de la calidad de los productos tipicos mediterráneos de origen animal, 26th September-2nd October. Badajoz and Zafra, Spain.

Poullet, B., Huertas, M., Sánchez, A., Cáceres, P., Larriba, G., 1991. Microbial study of Casar de Cáceres cheese throughout ripening. J. Dairy Res. 58, 231-238.

Rohm, H., Lechner, F., Brauer, M., 1992. Diversity of yeasts in selected dairy products. J. Appl. Bacteriol. 72, 370-376.

Roostita, R., Fleet, G.H., 1996. The occurrence and growth of yeasts in Camembert and Blue-veined cheeses. Int. J. Food Microbiol. 28, 393-404.

Sánchez, D., Carmona, M.A., Gómez, R., Fernández-Salguero, J., 1995. Evolucion de algunos grupos microbianos durante la maduracion del queso de Los Pedroches. Alimentaria 263, 87-90.

Tudor, E., Board, R., 1993. Food-spoilage yeasts. In: Rose, A., Harrison, J. (Eds.). The Yeasts, Vol. 5. Academic Press, London, pp. 435-508.

Van der Vossen, J.M., Hofstra, H., 1996. DNA based typing, identification and detection systems for food spoilage microorganisms: development and implementation. Int. J. Food Microbiol. 33, 35-49. 